\title{
Role of Medicinal Plants and Natural Products on Osteoporotic Fracture Healing
}

\author{
Mohd Azri Abd Jalil,, ${ }^{1,2}$ Ahmad Nazrun Shuid, ${ }^{1}$ and Norliza Muhammad ${ }^{1}$ \\ ${ }^{1}$ Department of Pharmacology, Faculty of Medicine, Universiti Kebangsaan Malaysia, Jalan Raja Muda Abd Aziz, \\ 50300 Kuala Lumpur, Malaysia \\ ${ }^{2}$ Department of Basic Medical Science, Kulliyyah of Nursing, International Islamic University Malaysia, Level 2, \\ Jalan Hospital Campus, P.O. Box 141, Pahang Darul Makmur, 25710 Kuantan, Malaysia \\ Correspondence should be addressed to Norliza Muhammad, norliza_ssp@yahoo.com
}

Received 13 June 2012; Accepted 17 July 2012

Academic Editor: Ima Nirwana Soelaiman

Copyright (๑) 2012 Mohd Azri Abd Jalil et al. This is an open access article distributed under the Creative Commons Attribution License, which permits unrestricted use, distribution, and reproduction in any medium, provided the original work is properly cited.

\begin{abstract}
Popularly known as "the silent disease" since early symptoms are usually absent, osteoporosis causes progressive bone loss, which renders the bones susceptible to fractures. Bone fracture healing is a complex process consisting of four overlapping phaseshematoma formation, inflammation, repair, and remodeling. The traditional use of natural products in bone fractures means that phytochemicals can be developed as potential therapy for reducing fracture healing period. Located closely near the equator, Malaysia has one of the world's largest rainforests, which are homes to exotic herbs and medicinal plants. Eurycoma longifolia (Tongkat Ali), Labisia pumila (Kacip Fatimah), and Piper sarmentosum (Kaduk) are some examples of the popular ethnic herbs, which have been used in the Malay traditional medicine. This paper focuses on the use of natural products for treating fracture as a result of osteoporosis and expediting its healing.
\end{abstract}

\section{Fracture}

Fracture is defined as a complete or incomplete separation in the continuity of the bone [1]. Fracture healing is a complex physiological process that involves the coordinated participation of hematopoietic and immune cells within the bone marrow. In conjunction with vascular and skeletal cell precursors, it also includes mesenchymal stem cells (MSCs), which are recruited from the circulation and the surrounding tissues $[2,3]$.

The two basic types of fracture healing are the primary or direct fracture healing and the secondary or indirect fracture healing. Primary (direct) fracture healing occurs with very minimal callus formation. It is a direct attempt of bone to reestablish its continuity and thus requires direct contact of cells in the cortex [4]. Primary healing occurs rarely as the majority of fracture repairs undergo secondary or indirect healing [5]. Based on the histological observations, secondary fracture healing occurs in four overlapping phases, which are haematoma formation, early inflammatory (two to four weeks), repair (proliferation and differentiation, within a month or two), and late remodelling phase (lasting for months or years) [6].

The clinical impact of fractures is substantial. Significant pain, disability, and deformity will trail following a fragility fracture. If the fracture union is not achieved, the patient may suffer long-term disability. Degenerative joint disease distal to the fracture and reflex sympathetic dystrophy are other recognized complications [7]. Hip fractures, even less common than vertebral fractures, contribute to the majority of the mortality, morbidity, and costs associated with osteoporosis [8]. Osteoporotic fractures are still an unsolved problem to the surgeon as well as for the patient. There are two ways of improving the fracture healing process: first, the developments of special implants to avoid implant failure; second, the improvement of bone quality to speed up and improve callus formation and otherwise to biologically advance implant fixation [9]. 


\section{Osteoporosis}

Osteoporosis is a heterogeneous cluster of abnormal processes characterized by the net loss of bone. It results in a decrease in total mineralized bone without a decrease in the ratio of bone mineral to the organic matrix $[10,11]$. As a result, there is a decrease in the overall amount of bone. The bone loss affects both cortical and trabecular bone, with trabecular bone loss more predominant in postmenopausal osteoporosis. Consequently, osteoporosis would lead to a bone with less tensile strength and significantly more susceptibility to fracture with less force [10]. This syndrome is clinically silent but progressive, usually only noted when a fracture occurs [12]. It is one of the most major public health problems with a mortality of $30 \%$ in the first year following the osteoporotic hip fracture [13].

During the early menopausal years in women, there is a dramatic reduction in circulating estrogen. As a result, there is an increase in the rate of bone resorption, but not reformation. This creates an imbalance and sets the stage for osteoporosis $[14,15]$. Although bone loss in women slows after the early postmenopausal years, loss continues through the latter decades of life, and in very old age the rate of loss increases again $[16,17]$. In addition to hormonal changes, age-related bone loss is also due to reduced ability to utilize calcium [18], decreased vitamin D supply due to lower production and reduced absorption, and decreased activation of vitamin D by the kidneys [19, 20]. All of these factors contribute to the increase with age in another hormone-parathyroid hormone $[21,22]$. When there is too much parathyroid hormone released in the body (hyperparathyroidism), bones release excessive calcium into the blood stream. As a direct result, bones lose their density and hardness.

\section{Osteoporosis in Male}

Although traditionally regarded as a disease of women, especially after menopause, osteoporosis also occurs frequently in men. Men steadily lose bone mineral density with aging, and one in five men over 50 will suffer an osteoporotic fracture [35]. Almost 30\% of all hip fractures are in men, and the mortality following a hip fracture is substantially higher in men than in women [36]. Men represent between $20 \%$ and $40 \%$ of all patients with each types of fracture that frequently affect the hip, vertebrae, forearm (wrist), and humerus. These fragility fractures may occur following minimal trauma such as a fall from standing height [37].

Bone loss in men has many causes, and often the same patient is affected by several of these. As in women, primary osteoporosis includes age-dependent and idiopathic osteoporosis. Age-related bone loss is dependent on estrogen production in both sexes, not only in women $[38,39]$. While estrogen is considered the female sex hormone, men also produce some estrogen. And as they age, men may experience a decrease in their ability to convert male sex hormones called androgens into estrogen [40,41]. Recent research suggests that estrogen deficiency and reduced levels of other sex hormones may be a cause of osteoporosis in men.
The main causes of secondary osteoporosis in men are excessive alcohol use, treatment with glucocorticoids, and hypogonadism, including that experienced by men receiving androgen deprivation therapy (ADT) for prostate cancer [42].

It is impossible to reverse the osteoporosis to its original form; it is just possible to prevent deterioration. Analgesic drug, heat, massage, and rest can be used to relief the osteoporotic pain [43]. The use of calcium, estrogen, calcitonin and vitamin $\mathrm{D}$ has been recommended too. Recently, few studies concerning the role of antioxidants in osteoporosis have been published, and the results show that there is a correlation between antioxidants and osteoporosis. Free radicals play an important role in many diseases such as diabetes, degenerative disorders, and cancer [44]. In normal conditions, there is a balance between free radicals and antioxidants defensive system. Sometimes, this balance is lost, which is called oxidative stress. Oxidative stress has been the centre of attention in recent studies of osteoporosis pathogenesis [45].

\section{Importance of Natural Product}

Today, it is estimated that about $80 \%$ of individuals in the developing countries still rely on traditional medicine-based largely on plants and animals for their primary health care. Herbal medicines are currently in demand, and their popularity is increasing day by day [46]. Herbal drugs are fairly preferred due to their effectiveness, fewer side effects, and relatively low cost [47]. It also has a brighter prospect in the global market. The market for ayurvedic medicines is estimated to be expanding at 20\% annually [48].

Due to some adverse effects or lack of efficacy of synthetic drugs, the potential efficacy of traditional medicines has stimulated the interest of scientists and doctors to turn on to traditional medicines for treatment of some chronic and difficult diseases, including the treatment for osteoporosis [49]. In traditional Chinese medicine (TCM), osteoporosis is classified as "rheumatism involving the bone" and "atrophic debility of bones" [50]. Based on the theory of "Kidney dominates bone" in TCM, many medicinal herbs have been prescribed to treat bone metabolic disorders for long time [51].

The Huang Di Nei Jing (The Yellow Emperor's Classic of internal Medicine) says, "The Meridians move the qi and blood. As a result, tendons and bones get nourished whereas joints get facilitated." Astragalus membranaceus Bge is one of the most popular herbs for restoring Qi and also can be applied for the osteoporosis treatment. The water extract of the root of A. membranaceus prevented osteoporosis induced by dexamethasone or by ovariectomy in rats by inhibiting osteoclast, decreasing bone absorption and promoting bone formation [23]. In TCM, Curculigo orchioides Gaertn., Epimedium grandiflorum Morr., Morinda officinalis How., Cistanche salsa G., Eucommia ulmoides Oliv., Psoralea corylifolia L., Cuscuta chinensis Lam., and Dipsacus japonicus Mip. possess the efficacy of tonifying kidney, strengthening Yang, and strengthening tendons and bones [24]. On 
TABLE 1: Table revealing earlier studies on traditional medicinal plants and their usage part.

\begin{tabular}{|c|c|c|c|}
\hline Plants & Part used & System of medicine & References \\
\hline Astragalus membranaceus Bge & Roots & Chinese & {$[23]$} \\
\hline Curculigo orchioides Gaertn & Rhizome & Chinese & {$[24]$} \\
\hline Epimedium grandiflorum Morr. & Roots and leaves & Chinese & {$[24]$} \\
\hline Morinda officinalis How. & Root & Chinese & {$[25]$} \\
\hline Cistanche salsa G. Beck & Stem & Chinese & {$[25]$} \\
\hline Eucommia ulmoides Oliv. & Bark & Chinese & {$[26]$} \\
\hline Psoralea corylifolia L. & Fruit & Chinese & {$[25]$} \\
\hline Cuscuta chinensis Lam. & Seed & Chinese & {$[25]$} \\
\hline Dipsacus japonicus Mip. & Root & Chinese & {$[24]$} \\
\hline Fructus Ligustri Lucidi & Fruit & Chinese & {$[24]$} \\
\hline Ficus religiosa & Young bark and stem bark & Ayurveda & {$[27]$} \\
\hline Cissus quadrangularis & Stems & Ayurveda & {$[28]$} \\
\hline Alangium salvifolium & Root bark & Ayurveda & {$[29]$} \\
\hline Christiella subpubescens & Rhizome and tuberous & Ayurveda & {$[29]$} \\
\hline Diospyros chloroxylon & Stem bark & Ayurveda & [29] \\
\hline Erythrina fusca & Seed & Ayurveda & [29] \\
\hline Mimosa intsia & Root & Ayurveda & [29] \\
\hline Phoenix loureiroi & Tender stem & Ayurveda & [29] \\
\hline Rhaphidophora pertusa & Aerial roots and leaves & Ayurveda & [29] \\
\hline Symplocos loba & Bark & Ayurveda & {$[30]$} \\
\hline Oryza sativa Linn & Fruits and roots & Ayurveda & {$[31]$} \\
\hline Eurycoma longifolia & Root & Malay & {$[32]$} \\
\hline Labisia pumila & Leaves and roots & Malay & {$[33]$} \\
\hline Piper sarmentosum & Leaves & Malay & {$[34]$} \\
\hline
\end{tabular}

the other hand, Fructus Ligustri Lucidi (FLL, Chinese name, Nvzhenzi) is one of the examples of herbs for nourishing Yin due to estrogen deficiency [52]. FLL can act on pituitary gland and further modulate endocrine function [53] and also useful in the prevention of bone marrow loss in cancer patients receiving chemotherapy [54].

The term "ayurveda" can be defined as knowledge (veda) of the lifespan (ayu). This knowledge is recorded in the ancient literature of India, referred to collectively as the Veda [55]. Ayurvedic medicine is based on breathing techniques, meditation, and yoga [56]. In Ayurvedic culture, the young bark of Ficus religiosa (family-Moraceae) also known as Ashwatha or Ashvattha, has been widely used in the treatment of bone fracture [27]. The stem bark cleaned with urine of a boy (below 7 years old) is taken and ground. Two spoonfuls of paste were administered twice daily for 21 days. Paste is also applied on the affected part and bandaged [29]. Cissus quadrangularis (family-Vitaceae), commonly known as the Asthishunkala, is an indigenous medicinal plant of India [57]. Methanolic extract of Cissus quadrangularis has been reported to promote the healing process of experimentally fractured radius-ulna of dogs, proven by radiological and histopathological examinations [28].

The native of Eastern Ghats (India's eastern coast area) use different types of plants to treat bone fractures. According to Eastern Ghats folklore, Alangium salvifolium, Christiella subpubescens, Diospyros chloroxylon, Erythrina fusca, Mimosa intsia, Phoenix loureiroi, and Rhaphidophora pertusa may be used for the treating bone fracture [29]. The bark of Symplocos loba is used externally for poulticing fractures, as it promotes the healing of bones [30]. Oryza sativa Linn (family-Poaceae), commonly known as Asian rice, is used in fracture healing and as a poultice to reduce inflammation at the affected areas [31]. Table 1 reveals the earlier studies on traditional medicinal plants by different cultures and their usage part.

\section{Malay Traditional Medicine}

The principles of Malay traditional medicine are generally based on the Arabic Unani medicine and Galenic philosophy in addition with other practices of Indonesian, Chinese, Indian, and orang asli (indigeneous people) traditional medicines [58]. It consists of chants (jampi), prayers (doa), massage, abstinence (pantang), and other practices, plus various natural resources from plants, animals, microorganisms and minerals for the purpose of treating and preventing illnesses, and for rehabilitation and health promotion. Medications containing single or compound medicinal plants may be dispensed in many forms, such as powders, capsules, pills, makjun, medicated oils, simple distillates, decoctions, infusions, paste, and poultices. Documentation of Malay TM practices is rather scarce. Most practices rely on old references, such as Mujarabat Melayu, Tajul Muluk, Tajus as Salatin, and Surat Tib Ubat [33]. The earliest scripts on 
the ethno-botanical uses of Malaysian plants dated back to the time of British colonialism. Some of these were publications [59, 60] providing monumental references for researchers on the utilization of medicinal plants in Malay traditional medicine.

\section{Tongkat Ali}

Eurycoma longifolia (EL) is a traditional medical plant known as Tongkat Ali in Malaysia, Tung Saw in Thailand, and Pasak Bumi in Indonesia. The plant is under the family of Simaroubaceaea. The water decoction of its root is a wellknown folklore medicine to enhance sexuality, fertility, and antiaging [61]. The herb contains Quassinoid alkaloid with properties curing Malaria, allergies, alleviating fevers and reduced tumors. The water-soluble extract contains among other things, tannins, high molecular weight polysaccharides, glycoproteins, and mucopolysaccharides [62].

Studies have revealed that EL contain eurycomanone, eurycomanol, eurycomalactone, and alkaloid that may help to increase the free testosterone level in the blood and also inhibit sex hormone binding globulin [63]. Testosterone has been approved to preserve bone mass development. Therefore, testosterone can help to prevent osteoporosis. Testosterone replacement could increase the mass and density of the bone and become efficient treatment for osteoporosis [64]. The main treatment to prevent diseases related to testosterone deficiency is hormone replacement therapy whereby testosterone is injected intramuscularly [65]. Some patients may refuse this treatment because of the painful administration of testosterone and its associated adverse effect, especially prostate cancer. Tongkat Ali can be used as an alternative to increase the testosterone level since EL is believed to have proandrogenic effect [66].

A study has shown that EL has a great potential as an alternative agent to testosterone replacement in treating androgen-deficient osteoporosis in men. It has good safety profile and convenient oral route of administration [32]. The active compound in EL can increase the level of testosterone in blood. The increase of testosterone can induce the androgen receptor, which is located in osteoblast and osteoclast cell. Testosterone and 5- $\alpha$-dihydrotestosterone can inhibit receptor activator of nuclear factor kappa- $\beta$ ligand (RANKL) and colony-forming unit-macrophages and further reducing osteoclast numbers [67]. As a result, the bone resorption process will be decreased and thus bone mass density will be maintained. These properties are essential in bone fracture healing process.

\section{Kacip Fatimah}

Kacip Fatimah, also known as Labisia pumila (LP), is a member of small genus of slightly woody plants of the family Myrsinaceae $[68,69]$. The locals know it by the name as Selusuh Fatimah, Rumput Siti Fatimah, Akar Fatimah, Pokok Pinggang, and Belangkas Hutan [60, 70]. Its water extract is traditionally consumed especially by the Malay women to treat menstrual irregularities and painful menstruation, help contracting birth passage after delivery, and to promote sexual health function [71]. It has also been used to treat dysentery, gonorrhoea, rheumatism, and sickness in bones $[72,73]$.

Postmenopausal women are prone to osteoporosis due to the reduction in estrogen level. Estrogen can induce osteoclasts apoptosis and inhibit osteoblasts apoptosis, which will indirectly reduce bone resorption and increase boneformation activity [74]. Proinflammatory cytokines such as, IL-6 and IL-1 may influence osteoclastogenesis by stimulating self-renewal and inhibiting the apoptosis of osteoclasts progenitors $[75,76]$. They promote osteoclasts differentiation which is an important stimulator of bone resorption that has been linked to accelerated bone loss seen in postmenopausal women [74]. Estrogen is able to suppress the production of these proinflammatory cytokines. LP, which has been opposed to exert phytoestrogen property, can be used as an alternative to estrogen replacement therapy (ERT) in postmenopausal inflammation-induced osteoporosis. In contrast to ERT, which can cause many harmful side effects, LP, which originated from natural resources, will not cause any side effect, if taken within its safe therapeutic dose [77].

Based on previous studies, LP has been shown to exhibit antioxidative properties due to the presence of flavanoids, ascorbic acid, beta-carotene, anthocyanin, and phenolic compounds [78, 79]. Flavonoid has been shown to be highly effective scavenger of free radicals that are involved in diseases such as osteoporosis and rheumatism, which is associated with aging due to oxidative stress [80]. Anthocyanin and phenolic, on the other hand, not only play a role as antioxidant agents, but also as anti-inflammatory agents $[52,81,82]$. These antioxidative and anti-inflammatory properties of LP extract explained the effectiveness of this medicinal plant against various diseases such as osteoporosis, rheumatism, and women sexual function.

\section{Kaduk}

Piper sarmentosum (PS) (Piperaceae, Malay name: Daun Kaduk) is a creeping shrub with erect branchlets that can grow up to $20 \mathrm{~cm}$. In Malay culture, the water decoction of its leaves is being used for treating diabetes, hypertension, cough, and joint aches [83]. The extract of the different parts of PS plant is known to possess benefits. It also possesses antioxidant, antiplasmodial, antituberculosis, antiinflammatory, anticarcinogenic, and hypoglycemic properties $[84,85]$. The methanolic extract of PS consists of a high natural antioxidant scavenger, naringenin, a flavonoid group with high superoxide scavenging activity [83]. Past experimental studies showed that flavonoids prevented ovariectomy-induced osteopenia and strengthened bone in ovariectomised animals [86]. Therefore, fracture healing properties of PS may be attributed to the action of flavonoids present in the PS extract.

A previous study on experimental fractured animal models revealed better fracture healing following PS administration during the late phase of fracture healing [34, 87]. In addition, Ima-Nirwana et al. [26] had observed 
an antiosteoporotic effect of PS aqueous extract in the adrenalectomised rats. The beneficial effect of PS on osteoporosis and fracture healing is most probably attributed to the antioxidative actions of the PS flavonoids, which may prevent oxidative stress [26]. Previous experimental studies on animals confirmed that osteopenia following oestrogen loss can be prevented by the supplementation of antioxidants [88]. It has also been found that glutathione peroxidase, an antioxidant enzyme secreted by osteoclasts, has a major role in reducing $\mathrm{H}_{2} \mathrm{O}_{2}$ [89]. Hence, supplementation of antioxidants can strengthen the bone and promote fracture healing in osteoporotic patients [90]. PS is rich in a natural antioxidant superoxide scavenger (Naringenin), which may have beneficial effect in promoting fracture healing most probably by reducing ROS through its free radical-scavenging activity. Hence, PS may have the potential to be added as antioxidant supplements to the current treatment modalities.

\section{Conclusion}

As a conclusion, a serious concern should be taken on osteoporosis. Because of the dormant properties of the disease, it is hard to recognize the symptoms until fracture occurs. Several studies have shown that androgen deficiency can lead to osteoporotic fractures. Therefore, various treatments should be considered to promote the healing period of the fracture. Natural products could be considered as a natural heritage from Mother Nature as a source of medicine. Thus, more extensive studies should be conducted to explore the healing properties of different types of medicinal plants to produce an alternative and effective treatment for the osteoporotic patient. A few of Malay's famous medicinal plants like EL, LP, and PS, can be used to enhance fracture healing. The plants possess the androgen-like and antioxidative properties, which are important in the promotion of bone fracture healing.

\section{References}

[1] D. L. Piermattei, G. L. Flo, and C. E. DeCamp, Handbook of Small Animal Orthopedics and Fracture Repair, Saunders Elsevier, St. Louis, Mo, USA, 4th edition, 2006.

[2] B. Gullberg, O. Johnell, and J. A. Kanis, "World-wide projections for hip fracture," Osteoporosis International, vol. 7, no. 5, pp. 407-413, 1997.

[3] X. Li, R. J. Quigg, J. Zhou, J. T. Ryaby, and H. Wang, "Early signals for fracture healing," Journal of Cellular Biochemistry, vol. 95, no. 1, pp. 189-205, 2005.

[4] P. Giannoudis, C. Tzioupis, T. Almalki, and R. Buckley, "Fracture healing in osteoporotic fractures: is it really different? A basic science perspective," Injury, vol. 38, supplement 1, pp. S90-S99, 2007.

[5] R. Jahagirdar and B. E. Scammell, "Principles of fracture healing and disorders of bone union," Surgery, vol. 27, no. 2, pp. 63-69, 2009.

[6] P. J. Harwood, J. B. Newman, and A. L. R. Michael, “(ii) An update on fracture healing and non-union," Orthopaedics and Trauma, vol. 24, no. 1, pp. 9-23, 2010.
[7] F. Cosman, "The prevention and treatment of osteoporosis: a review," Medscape General Medicine, vol. 7, no. 2, p. 73, 2005.

[8] N. F. Ray, J. K. Chan, M. Thamer, and L. J. Melton, "Medical expenditures for the treatment of osteoporotic fractures in the United States in 1995: report from the National Osteoporosis Foundation," Journal of Bone and Mineral Research, vol. 12, no. 1, pp. 24-35, 1997.

[9] E. K. Stuermer, S. Sehmisch, T. Rack et al., "Estrogen and raloxifene improve metaphyseal fracture healing in the early phase of osteoporosis. A new fracture-healing model at the tibia in rat," Langenbeck's Archives of Surgery, vol. 395, no. 2, pp. 163-172, 2010.

[10] L. S. Simon, "Osteoporosis," Clinics in Geriatric Medicine, vol. 21, no. 3, pp. 603-629, 2005.

[11] L. V. Avioli and R. Lindsay, "The female osteoporotic syndrome(s)," in Metabolic Bone Disease and Clinical Related Disorders, L. V. Avioli and S. M. Krane, Eds., W.B. Saunders, Philadelphia, Pa, USA, 1990.

[12] A. Kuttikat, R. Grant, and K. Chakravarty, "Management of osteoporosis," Journal of Indian Rheumatology Association, vol. 12, pp. 104-118, 2005.

[13] K. Kaveh, R. Ibrahim, M. Emadi, M. Z. A. Bakar, and T. A. Ibrahim, "Osteoporosis and bone health," Journal of Animal and Veterinary Advances, vol. 9, no. 6, pp. 1048-1054, 2010.

[14] T. Steiniche, C. Hasling, P. Charles, E. F. Eriksen, L. Mosekilde, and F. Melsen, "A randomized study on the effects of estrogen/gestagen or high dose oral calcium on trabecular bone remodeling in postmenopausel osteoporosis," Bone, vol. 10, no. 5, pp. 313-320, 1989.

[15] A. M. Parfitt, Z. H. Han, S. Palnitkar, D. S. Rao, M. S. Shih, and D. Nelson, "Effects of ethnicity and age or menopause on osteoblast function, bone mineralization, and osteoid accumulation in iliac bone," Journal of Bone and Mineral Research, vol. 12, no. 11, pp. 1864-1873, 1997.

[16] S. L. Hui, L. Zhou, R. Evans et al., "Rates of growth and loss of bone mineral in the spine and femoral neck in white females," Osteoporosis International, vol. 9, no. 3, pp. 200-205, 1999.

[17] A. C. Looker, H. W. Wahner, W. L. Dunn et al., "Updated data on proximal femur bone mineral levels of US adults," Osteoporosis International, vol. 8, no. 5, pp. 468-489, 1998.

[18] R. P. Heaney, "Vitamin D, nutritional deficiency, and the medical paradigm," Journal of Clinical Endocrinology and Metabolism, vol. 88, no. 11, pp. 5107-5108, 2003.

[19] A. R. Webb, C. Pilbeam, N. Hanafin, and M. F. Holick, "An evaluation of the relative contributions of exposure to sunlight and of diet to the circulating concentrations of 25hydroxyvitamin $\mathrm{D}$ in an elderly nursing home population in Boston," American Journal of Clinical Nutrition, vol. 51, no. 6, pp. 1075-1081, 1990.

[20] L. M. Salamone, G. E. Dallal, D. Zantos, F. Makrauer, and B. Dawson-Hughes, "Contributions of vitamin D intake and seasonal sunlight exposure to plasma 25-hydroxyvitamin D concentration in elderly women," American Journal of Clinical Nutrition, vol. 59, no. 1, pp. 80-86, 1994.

[21] R. L. Prince, I. Dick, A. Devine et al., "The effects of menopause and age on calcitropic hormones: a cross- sectional study of 655 healthy women aged 35 to 90," Journal of Bone and Mineral Research, vol. 10, no. 6, pp. 835-842, 1995.

[22] R. Eastell, A. L. Yergey, N. E. Vieira, S. L. Cedel, R. Kumar, and B. L. Riggs, "Interrelationship among vitamin D metabolism, true calcium absorption, parathyroid function, and age in women: evidence of an age-related intestinal resistance to 1,25-dihydroxyvitamin D action," Journal of Bone and Mineral Research, vol. 6, no. 2, pp. 125-132, 1991. 
[23] X. P. Liu, F. L. Chen, and Y. J. Cheng, "Study of total isoflavone from Astragalus membranaceuson on the prevention of osteoporosis in rats," Zhejiang JITCWM, vol. 15, no. 5, pp. 282-283, 2005.

[24] E. Li, D. J. Kong, X. H. Yang et al., "Effects of kidney-tonifying chinese medicinal herbs on prevention of rat osteoporosis," Chinese Journal of Osteoporosis, vol. 8, no. 2, pp. 166-170, 2002.

[25] F. Li, D. Wang, Z. Jiang, X. Gao, and H. Zhao, "Activity stimulating osteoblast-like cells proliferation of some traditional Chinese medicinal herbs and other plants," Pharmaceutical Biology, vol. 39, no. 5, pp. 351-356, 2001.

[26] S. Ima-Nirwana, M. R. Elvy-Suhana, O. Faizah, and S. Farihah, "Effects of Piper sarmentosum on bone resorption and its relationship to plasma cortisol in rats," Bone, vol. 44, pp. S79S80, 2009.

[27] K. R. Kirtikar and B. D. Basu, IndianMedicinal Plants, Periodical Experts Book Agency, New Delhi, India, 1993.

[28] D. K. Deka, L. C. Lahon, J. Saikia, and A. Mukit, "Effect of Cissus quadrangularis in accelerating healing process of experimentally fractured radius-ulna of dog: a preliminary study," Indian Journal of Pharmacology, vol. 26, no. 1, pp. 44-45, 1994.

[29] J. Suneetha, S. Prasanthi, B. V. A. Ramarao Naidu, and T. V. V. Seetharami Reddi, "Indigenous phytotherapy for bone fractures from Eastern Ghats," Indian Journal of Traditional Knowledge, vol. 10, no. 3, pp. 550-553, 2011.

[30] D. M. A. Jayaweera, Medicinal Plant (Indigenous and Exotic) Used in Ceylon, 1982.

[31] K. R. Kirtikar and B. D. Basu, Indian Medicinal Plant Vol. II, reprint ed. L.M. Basu, Allahabad, India, 1989.

[32] S. Ahmad Nazrun, A. B. Mohd Firdaus, A. S. Tajul Ariffin, M. Norliza, M. Norazlina, and S. Ima Nirwana, "The anti-osteoporotic effect of Eurycoma longifolia in aged orchidectomised rat model," The Aging Male, vol. 14, no. 3, pp. 150-154, 2011.

[33] A. J. Jamia, "Malay traditional medicine: an overview of scientific and technological progress," Tech Monitor, pp. 37-49, 2006.

[34] M. A. Estai, I. N. Soelaiman, A. N. Shuid, S. Das, A. M. Ali, and F. Suhaimi, "Histological changes in the fracture callus following the administration of water extract of Piper sarmentosum (Daun Kadok) in estrogen-deficient rats," Iranian Journal of Medical Sciences, vol. 36, pp. 281-288, 2011.

[35] S. Khosla, S. Amin, and E. Orwoll, "Osteoporosis in men," Endocrine Reviews, vol. 29, no. 4, pp. 441-464, 2008.

[36] S. Khosla, "Update in male osteoporosis," Journal of Clinical Endocrinology and Metabolism, vol. 95, no. 1, pp. 3-10, 2010.

[37] A. L. Sutton, L. Dian, and P. Guy, "Osteoporosis in men: an underrecognized and undertreated problem," British Columbia Medical Journal, vol. 53, no. 10, pp. 535-540, 2011.

[38] B. Ettinger, A. Pressman, P. Sklarin, D. C. Bauer, J. A. Cauley, and S. R. Cummings, "Associations between low levels of serum estradiol, bone density, and fractures among elderly women: the study of osteoporotic fractures," Journal of Clinical Endocrinology and Metabolism, vol. 83, no. 7, pp. 2239-2243, 1998.

[39] G. A. Greendale, S. Edelstein, and E. Barrett-Connor, "Endogenous sex steroids and bone mineral density in older women and men: the Rancho Bernardo study," Journal of Bone and Mineral Research, vol. 12, no. 11, pp. 1833-1843, 1997.

[40] S. Khosla and J. P. Bilezikian, "The role of estrogens in men and androgens in women," Endocrinology and Metabolism Clinics of North America, vol. 32, no. 1, pp. 195-218, 2003.

[41] C. W. Slemenda, C. Longcope, L. Zhou, S. L. Hui, M. Peacock, and C. C. Johnston, "Sex steroids and bone mass in older men. Positive associations with serum estrogens and negative associations with androgens," Journal of Clinical Investigation, vol. 100, no. 7, pp. 1755-1759, 1997.

[42] R. J. Lee, P. J. Saylor, and M. R. Smith, "Treatment and prevention of bone complications from prostate cancer," Bone, vol. 48, no. 1, pp. 88-95, 2011.

[43] M. Farzan, M. N. Tahmasebi, B. Aalami, M. R. Gits, and F. Frouzande, Textbook of Orthopaedics and Fractures, Tehran, Iran, 2003.

[44] E. Thomas, Andreoli, C. J. Charles, R. C. Carpenter, and J. 1. Griggs, Cecil Essentials of Medicine, W.B. Saunders, Philadelphia, Pa, USA, 2004.

[45] A. A. Behfar, N. Sadeghi, M. R. Oveisi et al., "The plasma antioxidant activity of superoxide dismutase enzyme in osteoporosis," Acta Medica Iranica, vol. 46, no. 6, pp. 441-446, 2008.

[46] S. Verma and S. P. Singh, "Current and future status of herbal medicines," Veterinary World, vol. 1, no. 11, pp. 347-350, 2008.

[47] S. Venkatesh, G. D. Reddy, B. M. Reddy, M. Ramesh, and A. V. N. A. Rao, "Antihyperglycemic activity of Caralluma attenuata," Fitoterapia, vol. 74, no. 3, pp. 274-279, 2003.

[48] E. Masood, "Medicinal plants threatened by over-use," Nature, vol. 385, no. 6617, p. 570, 1997.

[49] Y. Zhang, M. Wong, and C. Wu, "Anti-osteoporotic effects of medicinal herbs and their mechanisms of action," Asian Journal of Traditional Medicines, vol. 1, pp. 3-4, 2006.

[50] S. K. Zheng and R. Q. Nie, "Determination of treatment based in pathogenesis obtained through differentiation of symptoms and signs for osteoporosis," Chinese Medical Journal, vol. 12, no. 14, pp. 1204-1205, 2005.

[51] W. Xu, "Research progression of TCM on prevention for osteoporosis," Chinese Traditional Herbal Drugs, vol. 36, no. 2, pp. 314-315, 2005.

[52] S. Y. Wang and H. Jiao, "Scavenging capacity of berry crops on superoxide radicals, hydrogen peroxide, hydroxyl radical's, and singlet oxygen," Journal of Agricultural and Food Chemistry, vol. 48, no. 11, pp. 5677-5684, 2000.

[53] S. C. Hao, P. Bi, K. L. Yu, J. H. Sun, and L. Q. Ding, "Electron microscopic studies on the effect of a Chinese medicine Fructus Ligustri Lucidi on the corticotrophs of rats hypophyses," Journal of Tianjin Normal University, vol. 17, no. 3, pp. 49-52, 1997.

[54] D. Bown, Encyclopaedia of Herbs and Their Uses, Dorling Kindersley, London, UK, 1995.

[55] T. Nader, Human Physiology: Expression of Veda \& Vedic Literature, Maharishi Vedic University Press, Vlodrop, The Netherlands, 1994.

[56] R. J. Carroll, "Complementry and alternative medicine history, definitions, and what is it today?" in Complementary and Alternative Medicine Ethics, the Patient, and the Physician, L. Snyder, Ed., pp. 7-44, Humana Press, Philadelphia, Pa, USA, 2007.

[57] S. S. Chopra, M. R. Patel, and R. P. Awadhiya, "Studies on cissus quadrangularis in experimental fracture repair: a histopathological study," Indian Journal of Medical Research, vol. 64, no. 9, pp. 1365-1368, 1976.

[58] M. Zakaria and M. A. Mohd, Traditional Malay Medicinal Plants, Penerbit Fajar Bakti, Sdn. Bhd, Kuala Lumpur, Malaysia, 1994.

[59] J. D. Gimlette, Malay Poisons and Charm Cures, Oxford University Press, New York, NY, USA, 1971.

[60] I. H. Burkill, Dictionary of the Economic Products of the Malay Peninsula, Publisher Crown Agents for the Colonies, London, UK, 1935. 
[61] H. H. Ang and M. K. Sim, "Effects of Eurycoma longifolia Jack on sexual behaviour of male rats," Archives of Pharmacal Research, vol. 20, no. 6, pp. 656-658, 1997.

[62] K. L. Chan, C. Y. Choo, N. R. Abdullah, and Z. Ismail, "Antiplasmodial studies of Eurycoma longifolia Jack using the lactate dehydrogenase assay of Plasmodium falciparum," Journal of Ethnopharmacology, vol. 92, no. 2-3, pp. 223-227, 2004.

[63] H. H. Ang and H. S. Cheang, "Effects of Eurycoma longifolia Jack on laevator ani muscle in both uncastrated and testosterone-stimulated castrated intact male rats," Archives of Pharmacal Research, vol. 24, no. 5, pp. 437-440, 2001.

[64] L. Katznelson, J. S. Finkelstein, D. A. Schoenfeld, D. I. Rosenthal, E. J. Anderson, and A. Klibanski, "Increase in bone density and lean body mass during testosterone administration in men with acquired hypogonadism," Journal of Clinical Endocrinology and Metabolism, vol. 81, no. 12, pp. 4358-4365, 1996.

[65] A. Aminorroaya, S. Kelleher, A. J. Conway, L. P. Ly, and D. J. Handelsman, "Adequacy of androgen replacement influences bone density response to testosterone in androgen-deficient men," European Journal of Endocrinology, vol. 152, no. 6, pp. 881-886, 2005.

[66] J. M. Ali and J. M. Saad, Biochemical effect of Eurycoma longifolia Jack on the sexual behavior, fertility, sex hormone and glycolysis [Ph.D. dissertation], Department of Biochemistry, University of Malaya, 1993.

[67] D. M. Huber, A. C. Bendixen, P. Pathrose et al., "Androgens suppress osteoclast formation induced by RANKL and macrophage-colony stimulating factor," Endocrinology, vol. 142, no. 9, pp. 3800-3808, 2001.

[68] B. C. Stone, "Notes on the genus Labisia Lindl (Myrsinaceae)," Malayan Nature Journal, vol. 42, pp. 43-51, 1988.

[69] A. J. Jamia, P. J. Houghton, S. R. Milligan, and J. Ibrahim, “The Oestrogenis and cytotoxic effects of the extracts of Labisia pumila var. alata and Labisia pumila var. pumila in vitro," Malaysian Journal of Health Sciences, vol. 1, pp. 53-60, 1988.

[70] M. A. Rasadah and A. S. Zainon, Database on ASEAN Herbal and Medicinal Plants, vol. 1, ASEAN Publication, 2003.

[71] G. Bodeker, Health and Beauty from the Rainforest: Malaysian Traditions of Ramuan, Didier Millet, Kuala Lumpur, Malaysia, 1999.

[72] A. Fasihuddin, A. H. Rahman, and R. Hasmah, "Medicinal plants used by bajau community in sabah," in Trends in Traditional Medicine Research, K. L. Chan et al., Ed., pp. 493504, The School of Pharmaceutical Sciences, University of Science Malaysia, Penang, Malaysia, 1995.

[73] J. A. Jamal, P. J. Houghton, and S. R. Milligan, "Testing of Labisia pumila for oestrogenic activity using a recombinant yeast screen," Journal of Pharmacy and Pharmacology, vol. 50, no. 9, p. 79, 1998.

[74] S. C. Manolagas, "Birth and death of bone cells: basic regulatory mechanisms and implications for the pathogenesis and treatment of osteoporosis," Endocrine Reviews, vol. 21, no. 2, pp. 115-137, 2000.

[75] G. Girasole, G. Passeri, R. L. Jilka, and S. C. Manolagas, "Interleukin-11: a new cytokine critical for osteoclast development," Journal of Clinical Investigation, vol. 93, no. 4, pp. 1516-1524, 1994.

[76] R. L. Jilka, R. S. Weinstein, T. Bellido, A. M. Parfitt, and S. C. Manolagas, "Osteoblast programmed cell death (apoptosis): modulation by growth factors and cytokines," Journal of Bone and Mineral Research, vol. 13, no. 5, pp. 793-802, 1998.
[77] L. C. Hofbauer, C. R. Dunstan, T. C. Spelsberg, B. L. Riggs, and S. Khosla, "Osteoprotegerin production by human osteoblast lineage cells is stimulated by vitamin D, bone morphogenetic protein-2, and cytokines," Biochemical and Biophysical Research Communications, vol. 250, no. 3, pp. 776781, 1998.

[78] M. F. Wan Ezumi, S. Siti Amrah, A. W. M. Suhaimi, and S. S. J. Mohsin, "Evaluation of the female reproductive toxicity of aqueous extract of Labisia pumila var. alata in rats," Indian Journal of Pharmacology, vol. 39, no. 1, pp. 30-32, 2007.

[79] J. Huang, Y. Ogihara, H. Zhang, N. Shimizu, and T. Takeda, "Triterpenoid saponins from Ardisia mamillata," Phytochemistry, vol. 54, no. 8, pp. 817-822, 2000.

[80] H. Sies and W. Stahl, "Vitamins E and C, $\beta$-carotene, and other carotenoids as antioxidants," American Journal of Clinical Nutrition, vol. 62, no. 6, pp. 1315S-1321S, 1995.

[81] L. Bravo, "Polyphenols: chemistry, dietary sources, metabolism, and nutritional significance," Nutrition Reviews, vol. 56, no. 11, pp. 317-333, 1998.

[82] A. Cassidy, B. Hanley, and R. M. Lamuela-Raventos, "Isoflavones, lignans and stilbenes: origins, etabolism and potential importance tohuman health," Journal of the Science of Food and Agriculture, vol. 80, no. 7, pp. 1044-1062, 2000.

[83] V. Subramaniam, M. I. Adenan, A. R. Ahmad, and R. Sahdan, "Natural antioxidants: Piper sarmentosum (Kadok) and Morinda elliptica (Mengkudu)," Malaysian Journal of Nutrition, vol. 9, pp. 41-51, 2003.

[84] P. Peungvicha, S. S. Thirawarapan, R. Temsiririrkkul, H. Watanabe, J. Kumar Prasain, and S. Kadota, "Hypoglycemic effect of the water extract of Piper sarmentosum in rats," Journal of Ethnopharmacology, vol. 60, no. 1, pp. 27-32, 1998.

[85] S. H. Zainal Ariffin, W. H. H. Wan Omar, M. F. Safian, Z. Z. Ariffin, S. Senafi, and R. Megat Abdul Wahab, "Intrinsic anticarcinogenic effects of Piper sarmentosum ethanolic extract on a human hepatoma cell line," Cancer Cell International, vol. 9, article 6, 2009.

[86] M. N. Horcajada, V. Habauzit, A. Trzeciakiewicz et al., "Hesperidin inhibits ovariectomized-induced osteopenia and shows differential effects on bone mass and strength in young and adult intact rats," Journal of Applied Physiology, vol. 104, no. 3, pp. 648-654, 2008.

[87] M. A. Estai, F. H. Suhaimi, S. Das et al., "Piper sarmentosum enhances fracture healing in ovariectomized osteoporotic rats: a radiological study," Clinics, vol. 66, no. 5, pp. 865-872, 2011.

[88] J. M. Lean, J. T. Davies, K. Fuller et al., "A crucial role for thiol antioxidants in estrogen-deficiency bone loss," Journal of Clinical Investigation, vol. 112, no. 6, pp. 915-923, 2003.

[89] S. Muthusami, I. Ramachandran, B. Muthusamy et al., "Ovariectomy induces oxidative stress and impairs bone antioxidant system in adult rats," Clinica Chimica Acta, vol. 360 , no. 1-2, pp. 81-86, 2005.

[90] S. A. Sheweita and K. I. Khoshhal, "Calcium metabolism and oxidative stress in bone fractures: role of antioxidants," Current Drug Metabolism, vol. 8, no. 5, pp. 519-525, 2007. 


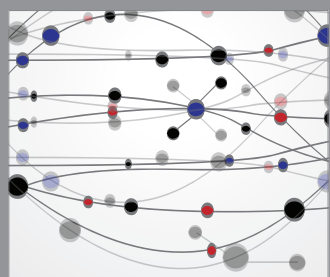

The Scientific World Journal
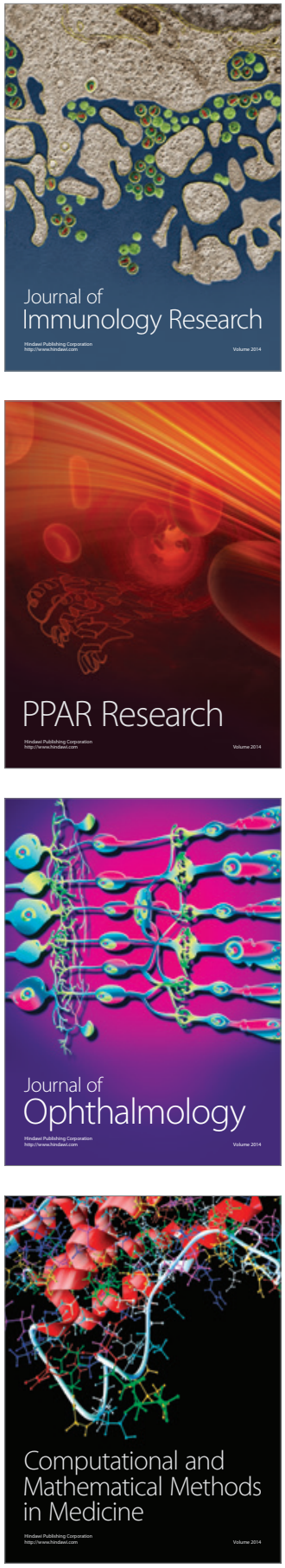

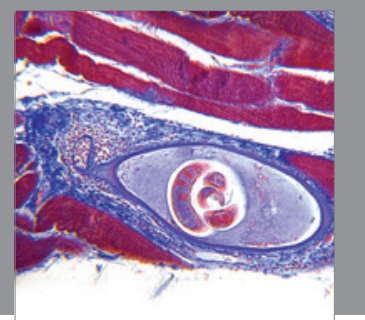

Gastroenterology

Research and Practice
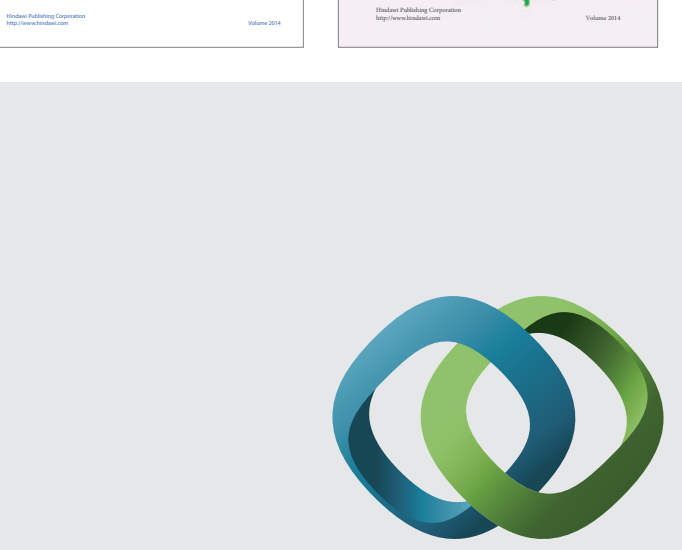

\section{Hindawi}

Submit your manuscripts at

http://www.hindawi.com
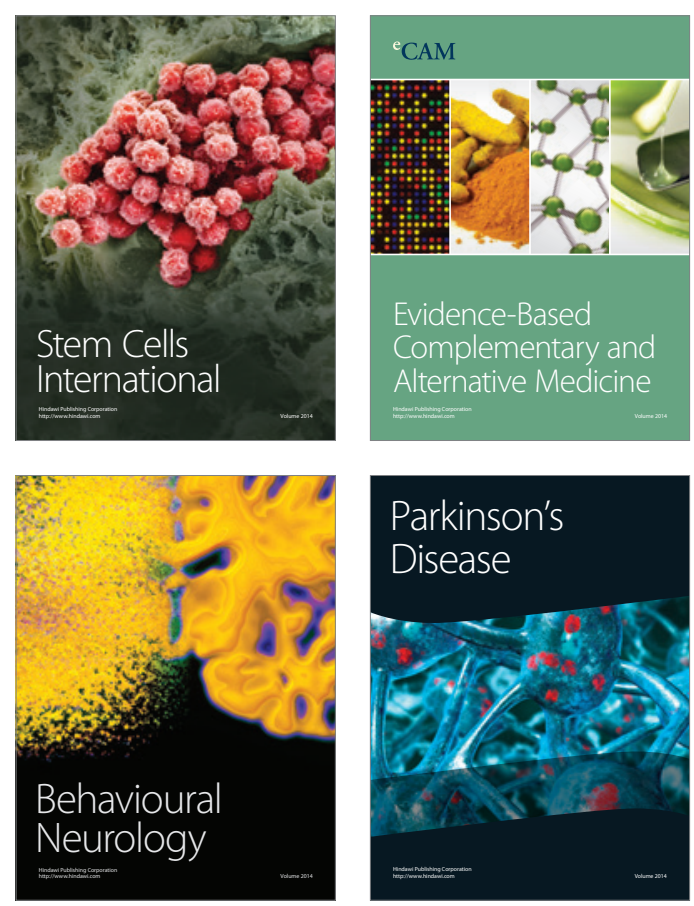

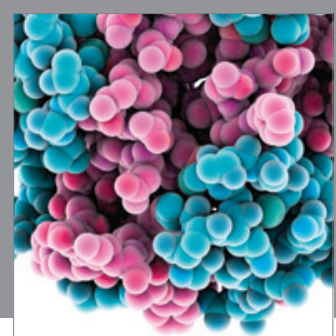

Journal of
Diabetes Research

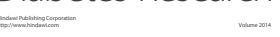

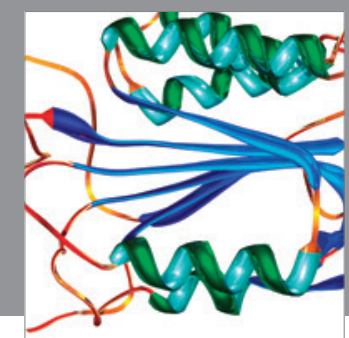

Disease Markers
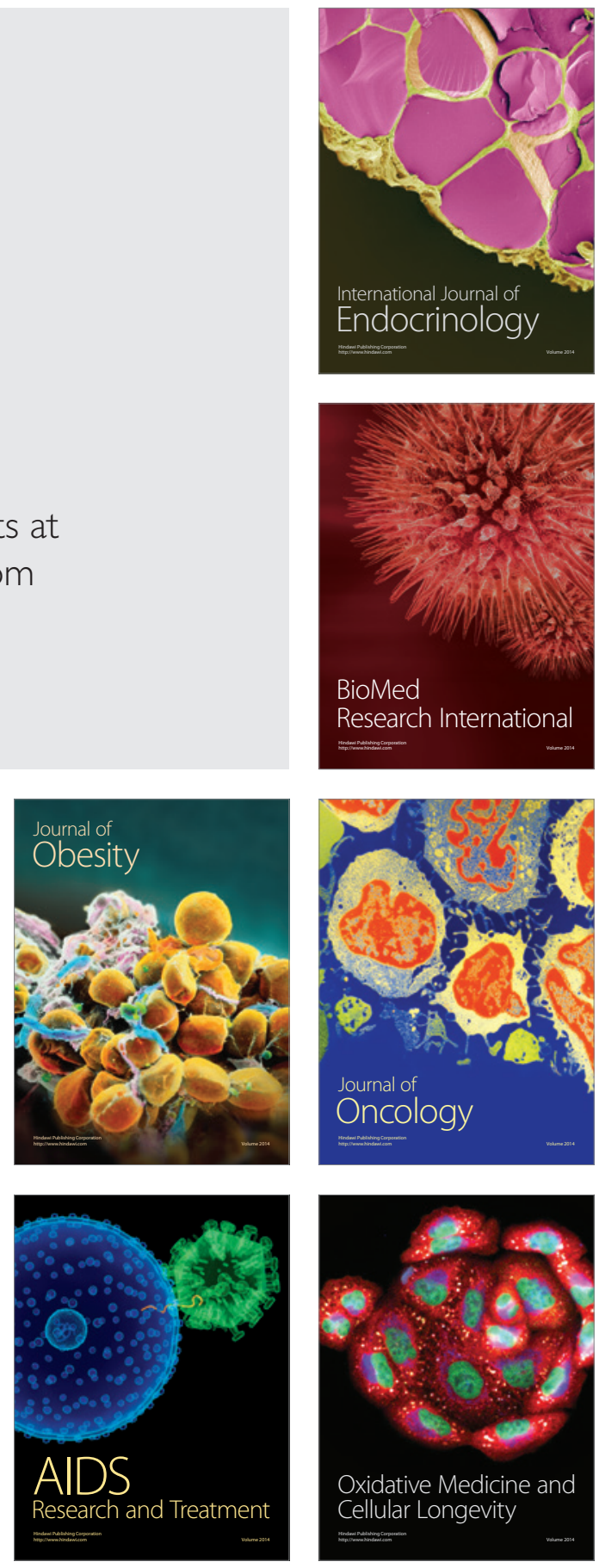